DOI: 10.46340/eujem.2021.7.3.2

Nonna Kobidze

ORCID ID: https://orcid.org/0000-0002-5493-2263

Vasyl' Stus Donetsk National University, Ukraine

\title{
APPROACHES TO THE TYPOLOGIZATION OF RISKS OF HIGHER EDUCATION INSTITUTION ACTIVITY AS AN ACTOR OF EDUCATIONAL SERVICES MARKET
}

\author{
Нонна Кобідзе \\ Донецький національний університет імені Василя Стуса, Україна

\section{ПІДХОДИ ДО ТИПОЛОГІЗАЦІї РИЗИКІВ ДІЯЛЬНОСТІ ЗАКЛАДУ ВИЩОЇ ОСВІТИ ЯК СУБ'ЄКТУ РИНКУ ОСВІТНІХ ПОСЛУГ}

The article proves, that in modern conditions for effective functioning and maintenance of competitiveness in the educational services market, higher education institutions are forced to form competent management, comprehensively investigate all negative factors, as well as develop and implement their own risk management systems. The study defines risk as a set of circumstances that can lead to adverse organizational and economic consequences for the educational services market actors (state, higher education institution, individual, etc.), including material damage, loss of reputation, lost profits, restrictions on the use of tangible and intangible resources. It is established that the peculiarities of risk management in higher education institutions are determined by the specifics of the service sector, significant state regulation of the educational services market, the dependence of the education system on the development of the labour market and other factors. It is proposed to classify risks based on primary and secondary characteristics, based on separation of external and internal factors and by educational services market actors, and this approach contributes to the most complete identification of risks and their relationship. The analysis of the existing classifications of risks allows to single out the place of each type of risk in the activities of the educational services market actors and to direct the necessary efforts to develop measures to protect them from negative impact. It is concluded that risk management in the education system, in the educational services market contributes to increasing the economic efficiency of higher education institutions, increasing their competitiveness, improving the quality of labour resources, improving planning and controlling in the education system, strengthening adaptation to changing environmental conditions, for the sustainable development of the education system.

Keywords: risk, typology, risk management, actors of educational services market, higher education institutions.

Постановка проблеми та її актуальність. Поява ринкових механізмів в економіці та їх перехід в інші сфери зумовила поширення терміну «ризик», що традиційно визначається в юридичному, фінансовому, комерційному напрямах. Незалежно від специфіки сфери вживання зазначеного терміну, ризик завжди передбачає можливість втрат, ймовірність невідповідності наміченим цілям розвитку. Діяльність закладів вищої освіти, як і будь-яких інших організацій, схильна до появи різних ризиків, тому в їх управлінні необхідно використовувати систему ризик-менеджменту. В даний час, незважаючи на те, що заклади вищої освіти багато в чому розвиваються за рахунок освітньої та наукової діяльності, що приносить певний дохід, система ризик-менеджменту в них не застосовується в повному обсязі та не входить в комплекс заходів при розробці та прийнятті управлінських рішень. За таких умов вивчення та систематизація ризиків, які є характерними для діяльності закладу вищої освіти як суб'єкту ринку освітніх послуг, є вкрай актуальним напрямом дослідження. 
Аналіз останніх досліджень і публікацій з теми дослідження. Управління фінансовими або комерційними ризиками стало предметом дослідження багатьох науковців, проте питанню управління ризиками в системі освіти присвячено лише невелика кількість наукових праць. Так, наприклад, загальним проблемам управління ризиками присвячені праці У. Бека ${ }^{1}$, Е. Гідденса ${ }^{2}$, Р. Доджа, М. Дугласа ${ }^{3}$, Г. Ешковіца ${ }^{4}$ Н. Лумана, К. Редхеда, С. Хьюїса, В. Хойера та інших авторів. Перші роботи саме на тему управління ризиками в сфері освіти були опубліковані в США і країнах Європи та були присвячені розробкам методики оцінки ризиків в коледжах і університетах, що мали суттєву наукову цінність у зв'язку з розвитком ринку освітніх послуг. Серед них особливої уваги заслуговують праці М. Ібанеску ${ }^{6}$ Б. Кларка ${ }^{7}$, М. Фуллана ${ }^{8}$, Д. Харгрівса ${ }^{9}$ та інших. У зазначених наукових працях розглянуті підходи до визначення ризиків, їх групування за часом виникнення, характером небезпеки, причинами збитків, місцем виникнення ризиків, рівнем прояву несприятливих наслідків. Проте, актуальним питанням залишається узагальнення та систематизація ризиків, які $\epsilon$ характерними саме для діяльності закладу вищої освіти як суб'єкту ринку освітніх послуг.

Метою статті $\epsilon$ визначення, узагальнення та систематизація підходів до типологізації існуючих ризиків діяльності закладу вищої освіти як суб'єкту ринку освітніх послуг.

Викладення основного матеріалу. Управління закладами вищої освіти в умовах глобалізаційних процесів, модернізації економіки та розвитку ринку освітніх послуг передбачає обов'язкове застосування сучасних управлінських технологій, таких як управління ризиками та управління знаннями. При цьому ризик визначається як сукупність обставин, здатних привести до несприятливих організаційних і економічних наслідків для суб'єкта ринку освітніх послуг (держави, закладу вищої освіти, індивіда тощо), включаючи матеріальні збитки, втрату репутації, недоотриманий прибуток, обмеження використання матеріальних і нематеріальних ресурсів.

Управління ризиками є одним з напрямків діяльності керівників закладів вищої освіти. Їх основна мета - ефективне використання ресурсів для досягнення оптимального результату, а результативність даного процесу слід оцінювати по мірі досягнення очікуваного стану. Тому управління ризиками слід аналізувати як управління процесами, що, однак, тісно пов'язані з управлінням організаційною структурою. Особливості управління ризиками діяльності закладів вищої освіти визначає специфіка сфери послуг, значне державне регулювання ринку освітніх послуг, залежність системи освіти від розвитку ринку праці та інші фактори ${ }^{10}$.

Науковий підхід до управління ризиками в діяльності закладів вищої освіти на першому етапі передбачає їх класифікацію. Аналізуючи роботи сучасних науковців, доцільно виокремити основні підходи до класифікації ризиків: на основі виділення первинних і вторинних ознак, що дозволяє здійснювати їх групування найбільш зручним способом з точки зору застосування механізмів та інструментів по їх управлінню; на основі виділення зовнішніх і внутрішніх факторів, що дає можливість оперативно ідентифікувати джерела ризиків та обирати відповідні методи по їх управлінню; за суб'єктами ринку освітніх послуг, що сприяє найбільш повній ідентифікації ризиків та їх взаємозв'язку.

Найбільш очевидними ризиками $є$ ті, з якими стикаються суб'єкти ринку освітніх послуг ${ }^{11}$. Для здобувачів вищої освіти, наприклад, актуальним є ризик незатребуваності спеціальності на ринку

\footnotetext{
${ }^{1}$ Beck, U. (1986). Risikogesellschaft. Frankfurt am Main: Suhrkamp, 391.

${ }^{2}$ Giddens, A. (1991). Fate, Risk and Security. Modernity and Self-Identity: Self and Society in the Late Modern Age. Cambridge: Polity Press.

${ }^{3}$ Douglas, M. (1990). Risk as a Forensic Resource. Dedalus, Fall, 4, 1-16.

${ }^{4}$ Etzkowitz, H. (2008). The Triple Helix: University-Industry-Government Innovation in Action. London: Routledge.

${ }^{5}$ Luhmann, N. (1991). Der Begriff Risiko. Soziologie des Risikos. Berlin: Walter de Gruyter, 9-40.

${ }^{6}$ Floricel, S., Ibanescu, M. (2008). Using R \& D portfolio management to deal with Dynamic Risk.

$R \& D$ Management, $38(5), 452-467$.

${ }^{7}$ Clark, B. (1998). Creating Entrepreneurial Universities: Organization Pathways of Transformation. Guildford, UK: Pergamon.

${ }^{8}$ Fullan, M. (2015). The New Meaning of Educational Change. Fifth Edition. Teachers College Press.

${ }^{9}$ Hargreaves, D. (1975). Interpersonal relation and education. London: R \& K. Paul, 34-87.

${ }^{10}$ Shaulska, L., Doronina, O., Naumova, M., Honcharuk, N., Bondarevska, K., Tomchuk, O. (2020).

Cross-country clustering of labor and education markets in the system of strategic economic management.

REICE-Revista Electronica de Investigacion en Ciencias Economicas, 8 (16), 166-193.

${ }^{11}$ Shaulska, L., Yakymova, N. (2015). Formation of educational potential of sustainable development. Scientific letters of academic society of Michal Baludansky, 3 (3), 140-146.
} 
праці через зміну його кон'юнктури або ризик отримати освіту низької якості. Головним ризиком для роботодавця $є$ додаткові фінансові витрати на перенавчання працівників, якщо їх кваліфікація не відповідає потрібному рівню. Для суспільства ризиковою $є$ ситуація соціальної напруженості при неадекватному функціонуванні ринку праці та неможливість для випускників закладів вищої освіти знайти роботу. Держава піддається ризику безробіття через несиметричне покриття кадрових потреб галузей економіки, а також ризику неефективного використання коштів на підготовку фахівців.

Важливою $є$ класифікація ризиків на основі виділення зовнішніх i внутрішніх факторів. Науковці, що досліджують проблеми управління ризиками діяльності закладів вищої освіти, виокремлюють внутрішні та зовнішні фактори, які представлені на рис. 1.

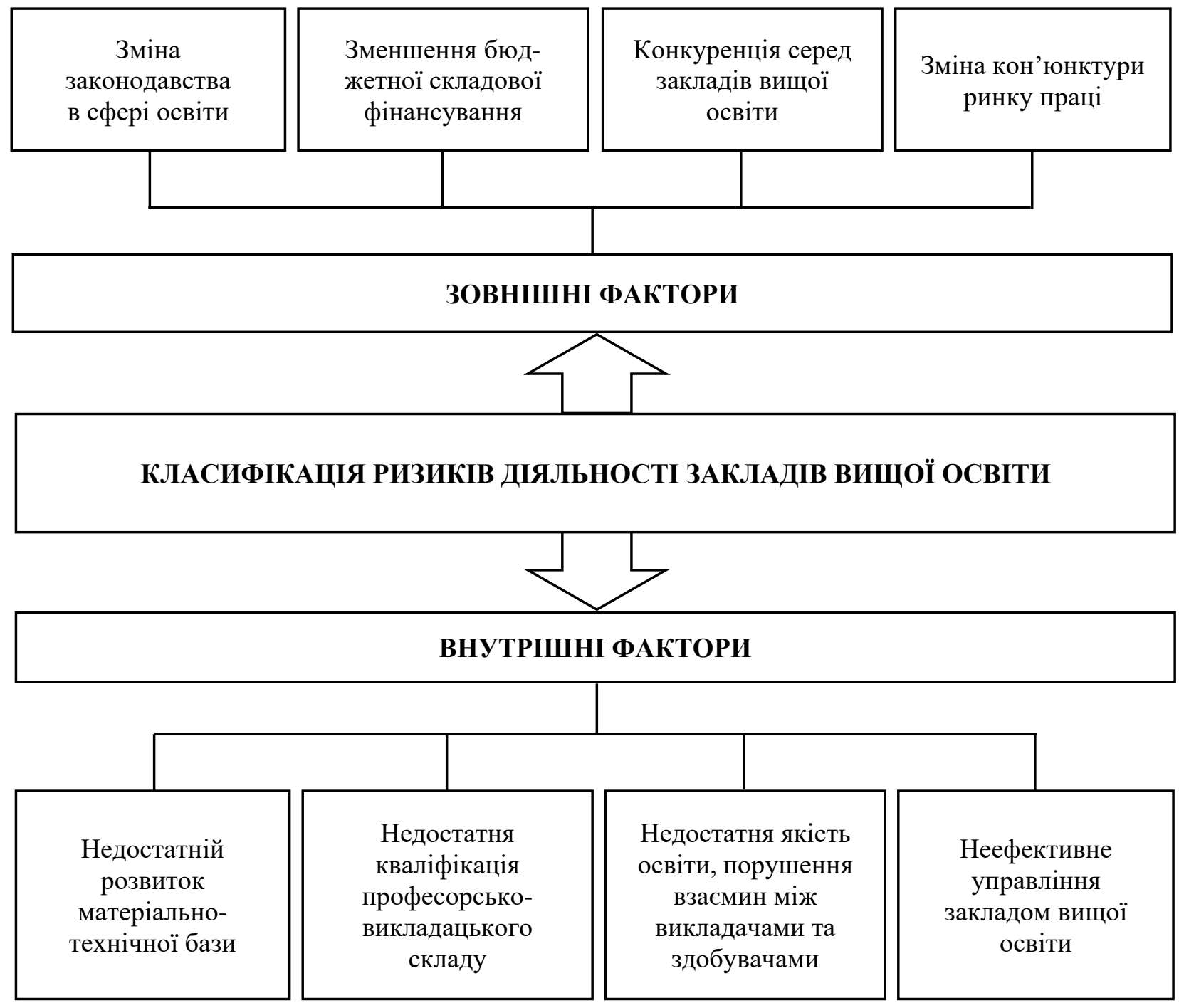

Рис. 1. Класифікація ризиків діяльності закладів вищої освіти на основі виділення зовнішніх і внутрішніх факторів

\section{Джерело: розроблено автором}

До основних зовнішніх факторів, що впливають на виникнення ризиків в сфері вищої освіти, можна віднести: перехід до суспільства знань, що належним чином не забезпечений ні матеріально, ні методично; швидке старіння трансльованого знання; наростання темпу соціальних змін; невисока конкурентоспроможність української системи освіти на глобальному ринку; невідповідність ринків праці та освітніх послуг; посилення соціального розшарування суспільства; демографічний спад; активне поширення Інтернет як глобальної мережі тощо. 
Внутрішні фактори пов'язані з функціонуванням і розвитком освіти як системи. Серед них можна виділити такі: недостатня якість та кваліфікація працівників всіх рівнів системи освіти; старіння професорсько-викладацького складу; відсутність необхідної інфраструктури; застаріла парадигма управління; слабка націленість на виробництво інновацій та інноваторів (зберігається проблема низької інноваційної активності закладів вищої освіти та їх незначного вкладу в розвиток національної інноваційної системи $)^{1}$; відсутність мобільності та системи підвищення кваліфікації науково-педагогічних кадрів всередині національної освітньої системи; зниження якості навчання.

Заслуговує на увагу розподіл ризиків за причинами виникнення на такі групи: політикоправові, фінансово-економічні, соціальні, техніко-технологічні, організаційно-технічні, кадрові (табл. 1).

Таблиця 1

Розподіл ризиків діяльності закладів вищої освіти за причинами виникнення

\begin{tabular}{|c|c|c|}
\hline № & Група ризиків & Причини виникнення ризиків \\
\hline 1 & Політико-правові ризики & $\begin{array}{l}\text { 1. Зміна пріоритетів державної політики в сфері освіти. } \\
\text { 2. Недосконалість механізмів реалізації державної політики } \\
\text { в сфері освіти на регіональному та місцевому рівнях. } \\
\text { 3. Зміна законодавства щодо регулювання діяльності } \\
\text { закладів вищої освіти. }\end{array}$ \\
\hline 2 & Фінансово-економічні ризики & $\begin{array}{l}\text { 1. Локальна або глобальна економічна криза. } \\
\text { 2. Зміна кон'юнктури ринку праці. } \\
\text { 3. Зростання конкуренції на ринку освітніх послуг. } \\
\text { 4. Недостатне бюджетне фінансування. } \\
\text { 5. Недосконалість механізмів залучення коштів партнерів } \\
\text { (гранти, спонсорські внески тощо). }\end{array}$ \\
\hline 3 & Соціальні ризики & $\begin{array}{l}\text { 1. Зниження чисельності населення. } \\
\text { 2. Посилення академічної мобільності. } \\
\text { 3. Зниження якості базових освітніх компетенцій. }\end{array}$ \\
\hline 4 & Техніко-технологічні ризики & $\begin{array}{l}\text { 1. Ускладнення техніки і технологій. } \\
\text { 2. Зростання вартості обладнання. }\end{array}$ \\
\hline 5 & $\begin{array}{l}\text { Організаційно-технічні } \\
\text { ризики }\end{array}$ & $\begin{array}{l}\text { 1. Невідповідність організаційної структури закладу вищої } \\
\text { освіти його цілям, завданням і функціям. } \\
\text { 2. Недостатній рівень матеріально-технічного забезпечення } \\
\text { закладу вищої освіти. } \\
\text { 3. Невідповідність технічним, санітарним, пожежним та } \\
\text { іншим нормам безпеки життєдіяльності. }\end{array}$ \\
\hline 6 & Кадрові ризики & $\begin{array}{l}\text { 1. Зниження професійно-кваліфікаційного рівня персоналу. } \\
\text { 2. Підвищення рівня плинності кадрів у закладі вищої } \\
\text { освіти. } \\
\text { 3. Порушення норм корпоративної культури. } \\
\text { 4. Демотивування персоналу закладу вищої освіти. } \\
\text { 5. Прояви професійних деструкцій. }\end{array}$ \\
\hline
\end{tabular}

Джерело: розроблено автором

Розглянувши основні групи ризиків діяльності закладів вищої освіти за причинами виникнення, до найбільш критичних можна віднести такі: ризик швидкого старіння трансльованого знання; ризик скорочення бюджетного фінансування; ризик відсутності висококваліфікованих викладачів; ризик невідповідності освітніх програм потребам ринку праці; ризик неконкурентоспроможності закладу вищої освіти на глобальному ринку.

Також доцільно виокремити класифікацію ризиків діяльності закладів вищої освіти в залежності від видів діяльності: ризики в освітній діяльності; ризики в науково-дослідній

\footnotetext{
${ }^{1}$ Shaulska, L., Yakymova, N., Krymova, M. (2020). Innovative employment in the structure of the modern labor market. European journal of transformation studies, 8 (1), 79-92.
} 
діяльності; ризики у фінансовій діяльності; ризики в сфері управління персоналом; ризики в сфері управління матеріально-технічною базою; ризики в забезпеченні безпеки. Запропонована класифікація більш детально представлена на рис. 2.

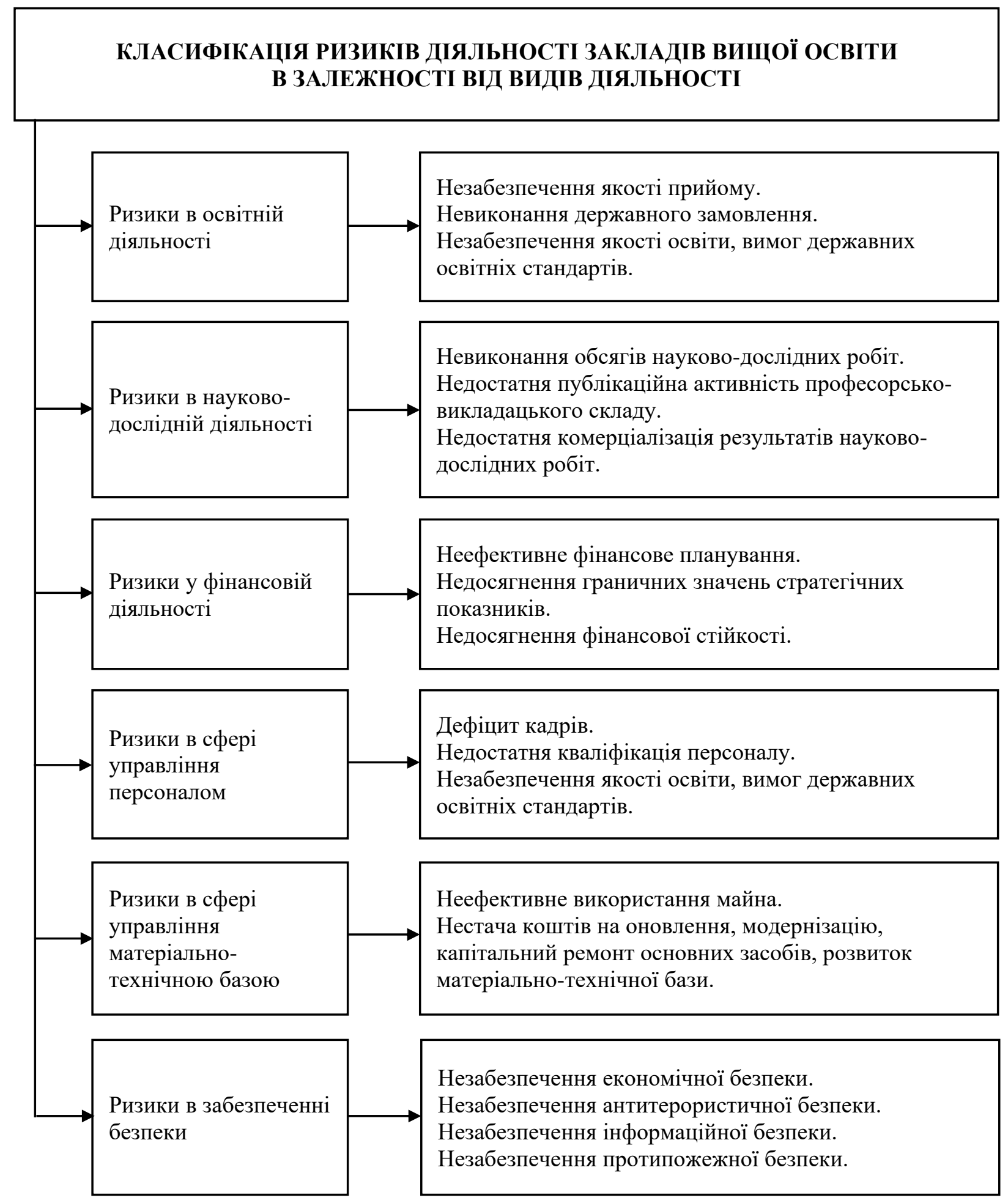

Рис. 2. Класифікація ризиків діяльності закладів вищої освіти в залежності від видів діяльності

Джерело: розроблено автором 
Наслідками зазначених ризиків можуть стати: невиконання цільових індикаторів закладом вищої освіти; порушення безпеки студентів, персоналу, майна; призупинення або позбавлення державної акредитації, ліцензії, заборона на прийом на навчання до закладу вищої освіти.

Отже, проведений аналіз існуючих класифікацій ризиків дозволяє виокремити місце кожного виду ризику в діяльності суб'єктів ринку освітніх послуг і направляти необхідні зусилля на розробку заходів щодо їх захисту від негативного впливу. Якщо правильно визначити, до якої групи належить ризик, то можна обирати найбільш ефективні методи управління ним. Ці можливості можуть бути використані при визначенні стратегії та тактики діяльності суб'єктів ринку освітніх послуг (держави, закладу вищої освіти, індивіда тощо).

Висновки. Таким чином, управління ризиками в системі освіти, на ринку освітніх послуг сприяє підвищенню економічної ефективності функціонування закладів вищої освіти, зростанню їх конкурентоспроможності, підвищенню якості трудових ресурсів, поліпшенню планування та контролінгу в системі освіти, посиленню адаптації до мінливих умов навколишнього середовища, забезпеченню умов для сталого розвитку системи освіти в цілому. Моделювання управління ризиками є важливим елементом системи управління закладами вищої освіти, дозволяє не тільки забезпечити застосування сучасних інформаційних та управлінських технологій в освіті, а й удосконалювати методологію та інформаційно-технологічну основу управління освітою на основі постійного моніторингу ризикового впливу зовнішнього і внутрішнього середовища закладів вищої освіти.

\section{References:}

1. Beck, U. (1986). Risikogesellschaft. Frankfurt am Main: Suhrkamp. [in English].

2. Giddens, A. (1991). Fate, Risk and Security. Modernity and Self-Identity: Self and Society in the Late Modern Age. Cambridge: Polity Press. [in English].

3. Douglas, M. (1990). Risk as a Forensic Resource. Dedalus: Fall. [in English].

4. Etzkowitz, H. (2008). The Triple Helix: University-Industry-Government Innovation in Action. London: Routledge. [in English].

5. Luhmann, N. (1991). Der Begriff Risiko. Soziologie des Risikos. Berlin: Walter de Gruyter. [in English].

6. Floricel, S., Ibanescu, M. (2008). Using R \& D portfolio management to deal with Dynamic Risk. $R \& D$ Management, 38 (5), 452-467. [in English].

7. Clark, B. (1998). Creating Entrepreneurial Universities: Organization Pathways of Transformation. Guildford, UK: Pergamon. [in English].

8. Fullan, M. (2015). The New Meaning of Educational Change. Fifth Edition. Teachers College Press. [in English].

9. Hargreaves, D. (1975). Interpersonal relation and education. London: R \& K. Paul. [in English].

10. Shaulska, L., Doronina, O., Naumova, M., Honcharuk, N., Bondarevska, K., Tomchuk, O. (2020). Cross-country clustering of labor and education markets in the system of strategic economic management. REICE-Revista Electronica de Investigacion en Ciencias Economicas, 8 (16), 166-193. [in English].

11. Shaulska, L., Yakymova, N. (2015). Formation of educational potential of sustainable development. Scientific letters of academic society of Michal Baludansky, 3 (3), 140-146. [in English].

12. Shaulska, L., Yakymova, N., Krymova, M. (2020). Innovative employment in the structure of the modern labor market. European journal of transformation studies, 8 (1), 79-92. [in English]. 